REFLECTIONS:

NEUROLOGY AND

THE HUMANITIES

Section Editor

Anne W. McCammon,

MD, FAAN

Vesper Fe Marie Llaneza

Ramos, MD

Correspondence \& reprint requests to Dr. Ramos:

vesper.ramos@yahoo.com

\title{
A Neurologist, an EMR, and a Patient
}

It was the day of our office's electronic medical record (EMR) launch. With all the commotion, it seemed as if we were launching a pop album or a movie, only people were not celebrating. Strangers wearing "SUPPORT" T-shirts populated our already cramped workstation. Neurologists hit their reflex hammers against the desks as they realized that, after attending two 4-hour classes on how to use this great EMR system, their log-ins did not work. Everybody was worried about having to type, but actually getting to the encounter to begin typing was already a challenge in itself. Abortive migraine pills were passed around.

As one of the younger physicians, I thought I would be okay. But it still took me 20 minutes of arguing over the Command Center trunk line for them to release my login. They insisted I had not taken the classes. Luckily, I had been in a class with one of our nurse practitioners, who vouched for me. And I hauled out the authoritative and demanding physician line, "My patient is waiting," which was true.

After that hurdle, the next problem was the nurses' learning curve. Rooming-in patients took 3 times as long as usual. The waiting area quickly looked like the boarding gate for a flight that was oversold or delayed. Even the "SUPPORT" team complained.

Finally, I was face-to-face with my first new patient and the brand-new EMR. It felt awkward to have that mammoth computer in between my patient and me. I could not even see her face. I introduced myself, made a little half joke/half apology about the new system and the delay in rooming-in. Then, I wholeheartedly declared that we would try to catch up as quickly as we could. My patient said she was "game." I thought she was quite understanding and I felt some relief. Unfortunately, that relief, or sense of gratitude, was not enough to prevent me from being irritated a few minutes into the encounter. Maybe I was stressed at running late. Maybe I was tired. I felt like I was in some scribing challenge where my fingers had to catch up with my ears and my patient's verbosity. It made me wonder if she was somehow a dummy test patient that the EMR geniuses set out randomly to assess my EMR handling capabilities. I reminded myself that I had seen the referral letter; I knew the referring doctor, and the distress the patient was showing would be worthy of an
Academy Award if she were just acting. She was a real patient.

She had multiple complaints and her story spanned more than a decade. She could not remember dates, changed her story more than twice, and had several crying spells. I offered her a tissue from behind the comfort of my monitor. In my schedule box, I could see the green lights shine on my next patients to be seen. It was going to be a long day. I felt the need to rush.

Her review of systems was positive for almost everything, much to my chagrin. I ticked box after box after box. Later on, I would feel shame for sounding like a call center agent instead of a concerned physician.

The EMR-guided interview seemed to take forever and drained me. The looming fear of a software crash also fought for my attention. I asked about past medical history (she had pseudoseizures and fibromyalgia), surgical history, family history, and finally, social history.

Oh, my Lord! Did I really have to ask about educational attainment in a patient without dementia? I maintained my composure, and kept on. In a monotone that was doing its best to hide my frustration, I asked all the elements.

"Have you ever been physically abused?" No.

"Have you ever been verbally abused?" No.

"Have you ever been sexually abused?" Yes.

I did not say anything but chose the "yes" button on the EMR. It told me: "Enter note." I bit my lower lip as I often do when a sudden shift in my routine comes about.

"Would you like to tell me more?" That was a genuine question that came from me without any prompting from the EMR.

She told me her brother first molested her when she was 5 years old. That lasted until she was well into her teens, after which she was raped by a stranger, and after that her brother-in-law raped her. My note on the EMR reads " 5 years old - brother, then stranger, then brotherin-law." That note did no justice whatsoever to the current of emotions inside the room. I was actually relieved that she could not see my face. But I wanted to see hers. So I pushed the computer aside and I looked at my patient, and I saw her in a way I had not seen her before.

"I'm sorry." That was all I could say.

Listen to Dr. Ramos read this story, available exclusively on Neurology ${ }^{\circledR}$ for the iPad ${ }^{\circledR}$. 
"Thank you. That's the first time anyone ever said sorry for that." She was calm. She looked weary and tired, but she had a well-defined bone structure, and I imagined her as a 5-year-old child, smiling and beaming. She would have been so beautiful. And I also saw how that beautiful face would have been so scared. She told me that she had never told anyone about her brother molesting her. He was dead now, anyway.

My patient was 54 years old, and it had taken almost 50 years for her to hear an apology for such a travesty. It should not have been from a rushed, irritable physician completing an EMR! I thought there was something very wrong with that, perhaps because I imagined a life that could have been or that should have been different. I do not know. There was definitely transference/countertransference at play.

The computer made a subtle beep and brought me back to my white-coated role. The monitor read: "Idle time. You will be logged off in 30 seconds if no action is made." In the lower corner was a timekeeper showing I was behind schedule. I felt the need to rush once more. The EMR was keeping me on track.

So I proceeded with the exam. I wanted to be gentle, but at the same time I felt enormous pressure to be quick and efficient. As expected, the exam was normal. I explained the tests that we needed to do, and I searched for these on the EMR order set. There were quite a number of awkward silences for which I apologized, and to which my patient just kept saying, "That's okay. I'm game." It offered me relief to hear her say that then. In hindsight, I wondered if that had always been her response to her abusers. But no response would ever justify an abusive situation. Still, I reminded myself that we live in an unjust world, where victims can be blamed, even if they never should. I wondered if her abusers would have interpreted her years of silence as consent to the abuse. Then I told myself I had no time to cater to an overactive imagination. I juggled completing the EMR tasks and answering her questions. I needed to make up time.

The after-visit summary was printed out. I handed it to her, saying "Good luck." I don't know why I even said it. She thanked me, and said, "Good luck with the new computer." I thanked her.

At that time, I could not just pause and reflect with clinic time ticking. It was an abrupt ending to an encounter, which may very well be just one among many. Like the average EMR, somewhere in between these words lies a wealth of information, and with some thought and reflection, perhaps lessons of a lifetime that needed to be passed on. True, this may very well be just another story. To put something on the record is to put it out for anyone who cared enough to get what he must from it. Knowledge is volatile; wisdom is enduring. One of the strengths of EMRs and written works is data mining, so new learning can be made, even beyond the intention of the original author or encoder.

If the point I am trying to make is unclear, I apologize. I described the difficulties of a new EMR, and the awkwardness and impersonal, but necessary nature of its use. I told the story of an abused woman with psychosomatic complaints. The common thread that tied these 2 elements is the neurologist, asked to handle both EMR and patient. This is the same neurologist who is still figuring out the learning that should come with the encounter. I think it is important to struggle and adapt to make this process easier, more efficient and perhaps, if possible, more humane.

One cannot ponder so long, however, for soon, idle time will log us all off. And we have no need for empty after-visit summaries. We get what we put in. Apologies may be all that could get out, but they will never feel enough.

Good luck to us all, indeed. 


\title{
Neurology
}

\author{
A Neurologist, an EMR, and a Patient \\ Vesper Fe Marie Llaneza Ramos \\ Neurology 2012;79;2079-2080 \\ DOI 10.1212/WNL.0b013e3182749f5d
}

This information is current as of November 12, 2012

\section{Updated Information \& Services}

\section{Subspecialty Collections}

Permissions \& Licensing

Reprints including high resolution figures, can be found at: http://n.neurology.org/content/79/20/2079.full

This article, along with others on similar topics, appears in the following collection(s):

\section{All Ethics in Neurology/Legal issues}

http://n.neurology.org/cgi/collection/all_ethics_in_neurology_legal_iss ues

Clinical neurology history

http://n.neurology.org/cgi/collection/clinical_neurology_history

Computer use in education

http://n.neurology.org/cgi/collection/computer_use_in_education

Electronic medical records

http://n.neurology.org/cgi/collection/electronic_medical_records

Professional conduct and ethics

http://n.neurology.org/cgi/collection/professional_conduct_and_ethics

Information about reproducing this article in parts (figures,tables) or in its entirety can be found online at:

http://www.neurology.org/about/about_the_journal\#permissions

Information about ordering reprints can be found online:

http://n.neurology.org/subscribers/advertise

Neurology ${ }^{\circledR}$ is the official journal of the American Academy of Neurology. Published continuously since 1951, it is now a weekly with 48 issues per year. Copyright (C 2012 American Academy of Neurology. All rights reserved. Print ISSN: 0028-3878. Online ISSN: 1526-632X.

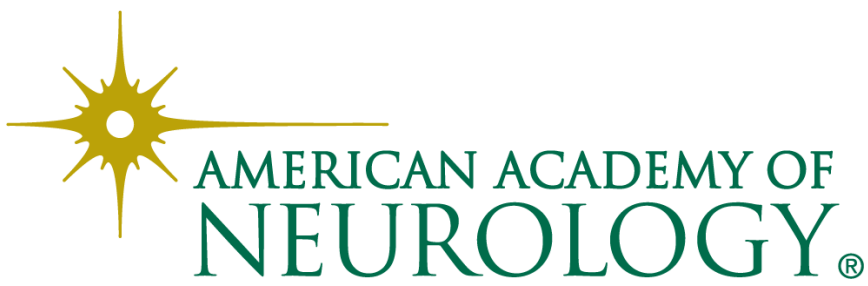

